\title{
Associations of estimated glomerular filtration rate and albuminuria with mortality and renal failure by sex: a meta-analysis
}

\section{Dorothea Nitsch clinical senior lecturer ${ }^{1}$, Morgan Grams assistant professor ${ }^{2}$, Yingying Sang biostatistician $^{3}$, Corri Black senior clinical lecturer ${ }^{4}$, Massimo Cirillo associate professor ${ }^{5}$, Ognjenka Djurdjev corporate director ${ }^{6}$, Kunitoshi Iseki director ${ }^{8}$, Simerjot K Jassal clinical professor ${ }^{9}$, Heejin Kimm assistant professor ${ }^{10}$, Florian Kronenberg professor ${ }^{11}$, Cecilia M Øien associate professor ${ }^{12}$, Andrew S Levey professor ${ }^{13}$, Adeera Levin professor ${ }^{7}$, Mark Woodward professor ${ }^{14}$, Brenda R Hemmelgarn associate professor ${ }^{15}$, for the Chronic Kidney Disease Prognosis Consortium}

\begin{abstract}
${ }^{1}$ Faculty of Epidemiology and Population Health, London School of Hygiene and Tropical Medicine, London, UK; ${ }^{2}$ Department of Medicine, Division of Nephrology, Johns Hopkins University School of Medicine, Baltimore MD, USA; ${ }^{3}$ Department of Epidemiology, Johns Hopkins Bloomberg School of Public Health, Baltimore MD, USA; ${ }^{4}$ Chronic Disease Research Group, Medical School, Aberdeen, UK; ${ }^{5}$ Department of Medicine (Nephrology), University of Salerno, Baronissi (SA), Italy; ${ }^{6}$ Provincial Health Services Authority, Vancouver BC, Canada; ${ }^{7}$ Division of Nephrology UBC, St.Pauls Hospital, Vancouver BC, Canada; ${ }^{8}$ Dialysis Unit, University Hospital of the Ryukyus, Okinawa, Japan; ${ }^{9}$ VA San Diego Healthcare System, Division of GIM/G, San Diego CA, USA; ${ }^{10}$ Institute for Health Promotion, Department of Epidemiology and Health Promotion, Graduate School of Public Health, Yonsei University, Seoul, Korea; ${ }^{11}$ Division of Genetic Epidemiology, Department of Medical Genetics, Molecular and Clinical Pharmacology, Innsbruck Medical University, Innsbruck, Austria; ${ }^{12}$ St Olavs Hospital, Department of Medicine, Section of Nephrology, Trondheim, Norway; ${ }^{13}$ Division of Nephrology, Department of Medicine, Tufts Medical Center, Boston MA, USA $;{ }^{14}$ George Institute for Global Health, Camperdown NSW, Australia; ${ }^{15}$ Division of Nephrology, Foothills Medical Centre, Calgary AB, Canada
\end{abstract}

\begin{abstract}
Objective To assess for the presence of a sex interaction in the associations of estimated glomerular filtration rate and albuminuria with all-cause mortality, cardiovascular mortality, and end stage renal disease.

Design Random effects meta-analysis using pooled individual participant data.

Setting 46 cohorts from Europe, North and South America, Asia, and Australasia.

Participants 2051158 participants (54\% women) from general population cohorts ( $n=1861052)$, high risk cohorts ( $n=151494)$, and chronic kidney disease cohorts ( $n=38$ 612). Eligible cohorts (except chronic kidney disease cohorts) had at least 1000 participants, outcomes of either mortality or end stage renal disease of $\geq 50$ events, and baseline
\end{abstract}

measurements of estimated glomerular filtration rate according to the Chronic Kidney Disease Epidemiology Collaboration equation $\left(\mathrm{mL} / \mathrm{min} / 1.73 \mathrm{~m}^{2}\right)$ and urinary albumin-creatinine ratio $(\mathrm{mg} / \mathrm{g})$.

Results Risks of all-cause mortality and cardiovascular mortality were higher in men at all levels of estimated glomerular filtration rate and albumin-creatinine ratio. While higher risk was associated with lower estimated glomerular filtration rate and higher albumin-creatinine ratio in both sexes, the slope of the risk relationship for all-cause mortality and for cardiovascular mortality were steeper in women than in men. Compared with an estimated glomerular filtration rate of 95 , the adjusted hazard ratio for all-cause mortality at estimated glomerular filtration rate 45 was $1.32(95 \% \mathrm{Cl} 1.08$ to 1.61$)$ in women and $1.22(1.00$ to 1.48$)$ in men $\left(P_{\text {interaction }}<0.01\right)$. Compared with a urinary albumin-creatinine ratio 
of 5 , the adjusted hazard ratio for all-cause mortality at urinary albumin-creatinine ratio 30 was 1.69 (1.54 to 1.84) in women and 1.43 (1.31 to 1.57$)$ in men $\left(P_{\text {interaction }}<0.01\right)$. Conversely, there was no evidence of a sex difference in associations of estimated glomerular filtration rate and urinary albumin-creatinine ratio with end stage renal disease risk.

Conclusions Both sexes face increased risk of all-cause mortality, cardiovascular mortality, and end stage renal disease with lower estimated glomerular filtration rates and higher albuminuria. These findings were robust across a large global consortium.

\section{Introduction}

Chronic kidney disease affects $10-16 \%$ of the general adult population in Asia, Europe, Australia, and the United States. ${ }^{1-6}$ Chronic kidney disease, typically defined by reduced estimated glomerular filtration rate and/or albuminuria, is independently associated with an increased risk of all-cause mortality and cardiovascular mortality and progression to end stage renal disease..$^{7-9}$ Go and colleagues found in administrative healthcare data that estimated glomerular filtration rates $<60$ $\mathrm{mL} / \mathrm{min} / 1.73 \mathrm{~m} 2$ were independently associated with hospitalisations, cardiovascular events, and death. ${ }^{10}$ In a collaborative meta-analysis of general population cohorts we found that mortality rises exponentially with decreasing estimated glomerular filtration rate below $60 \mathrm{~mL} / \mathrm{min} / 1.73 \mathrm{~m}^{2}$, while albuminuria shows linear association across its entire measurement range. ${ }^{8}$ Recent data indicate that the risk associated with estimated glomerular filtration rate is even stronger when glomerular filtration rate is estimated using the more accurate equation developed by the Chronic Kidney Disease Epidemiology Collaboration. ${ }^{11} 12$

Existing data regarding potential sex differences in the risk of chronic kidney disease suggest that women have a lower incidence of end stage renal disease, ${ }^{13}{ }^{14}$ lower cardiovascular risk, ${ }^{15}$ and (in countries with low maternal mortality) lower risk of all-cause mortality than men. ${ }^{16}$ Whether sex differences exist with respect to estimated glomerular filtration rate and albuminuria levels and adverse outcomes, and in particular whether such differences exist based on the combined effect of estimated glomerular filtration rate and albuminuria, is largely unknown.

Given the clinical uncertainty, we sought to determine if sex modifies the association between estimated glomerular filtration rate and albuminuria with all-cause and cardiovascular mortalities and end stage renal disease, using a global consortium of 46 cohorts and more than two million participants.

\section{Methods}

\section{Chronic Kidney Disease Prognosis Consortium study design}

The Chronic Kidney Disease Prognosis Consortium study ${ }^{7-9} 17$ includes data from general population cohorts, cohorts at high risk of cardiovascular events, and cohorts with chronic kidney disease. These cohorts are described in appendices 1-3 on bmj.com. Eligible cohorts contained at least 1000 participants (except chronic kidney disease cohorts), outcomes of either mortality or end stage renal disease with a minimum of 50 events, and baseline information on estimated glomerular filtration rate and albuminuria. Measures of albuminuria included the albumin-creatinine ratio (the preferred measure), ${ }^{17-19}$ protein-creatinine ratio, and qualitative measures using dipstick proteinuria. Adult participants (aged $\geq 18$ years) were included.

\section{Study covariates}

The equation developed by the Chronic Kidney Disease Epidemiology Collaboration was used to estimate glomerular filtration rate in $\mathrm{mL} / \mathrm{min} / 1.73 \mathrm{~m}^{2} .{ }^{120}$ In general population and high risk cohorts, estimated glomerular filtration rate was categorised as <15, 15-29, 30-44, 45-59, 60-74, 75-89, $90-104$, or $\geq 105 \mathrm{~mL} / \mathrm{min} / 1.73 \mathrm{~m}^{2}$, according to current clinical guidelines. ${ }^{821}$ Albuminuria was categorised as "negative," "high normal," "mild," or "heavy" depending on whether urinary albumin-creatinine ratio or urinary dipstick tests were available (urinary albumin-creatinine ratio <10, 10-29, 30-299, $\geq 300$ $\mathrm{mg} / \mathrm{g}$; dipstick proteinuria negative, trace, $1+, 2+$ or more). These categories were adapted for chronic kidney disease cohorts to reflect the lower levels of estimated glomerular filtration rate (categories $<15,15-29,30-44,45-74, \geq 75$ $\mathrm{mL} / \mathrm{min} / 1.73 \mathrm{~m}^{2}$ ) and higher levels of albuminuria or proteinuria (albumin-creatinine ratio <30, 30-299, 300-999, $\geq 1000 \mathrm{mg} / \mathrm{g}$; protein-creatinine ratio $<50,50-499,500-1,499, \geq 1,500 \mathrm{mg} / \mathrm{g}$ ). To derive urinary albumin-creatinine ratio or protein-creatinine ratio in $\mathrm{mg} / \mathrm{mmol}$ from the $\mathrm{mg} / \mathrm{g}$ cut-off values, we divided them by 8.84 . For ease of reading, we have omitted units for estimated glomerular filtration rate and urinary albumin-creatinine ratio in the remainder of this manuscript.

Demographic factors included age (continuous), sex, and ethnicity (black $v$ non-black). Comorbidities included a history of cardiovascular disease (includes previous myocardial infarction, coronary revascularisation, heart failure, or stroke) and diabetes (fasting glucose concentration $\geq 7.0 \mathrm{mmol} / \mathrm{L}(\geq 126$ $\mathrm{mg} / \mathrm{dL})$, non-fasting glucose concentration $\geq 11.1 \mathrm{mmol} / \mathrm{L}(\geq 200$ $\mathrm{mg} / \mathrm{dL}$ ), haemoglobin $\mathrm{A}_{1 \mathrm{c}} \geq 6.5 \%$ ( $\left.\geq 48 \mathrm{mmol} / \mathrm{mol}\right)$, use of glucose lowering drugs, or self reported diabetes). Smoking was dichotomised as current versus former or never smokers, and body mass index was calculated (weight $(\mathrm{kg}) /\left(\right.$ height $\left.(\mathrm{m})^{2}\right)$. Baseline systolic blood pressure $(\mathrm{mm} \mathrm{Hg})$ was used as a continuous variable (appendix 2 on bmj.com). Serum total cholesterol (mmol/L, continuous) was available in a subset of cohorts (appendix 2).

\section{Study outcomes}

The primary study outcomes were all-cause mortality, cardiovascular mortality, and end stage renal disease. Cardiovascular mortality was defined as death due to myocardial infarction, heart failure, stroke, or sudden cardiac death. End stage renal disease was defined as initiation of renal replacement therapy or death due to kidney disease (other than acute kidney injury).

\section{Statistical analysis}

Analysis was performed in two stages: the first was a standard analysis within each cohort using centrally developed statistical code, the second pooled results in a meta-analysis (see appendix 2). Analyses were done using Stata version 11.2.

\section{Stage 1: within-cohort analysis}

For the 44 cohorts with data from both women and men, subjects with missing baseline values for estimated glomerular filtration rate or urinary albumin-creatinine ratio or dipstick tests were excluded. Cox proportional hazards models adjusted for study covariates (age, sex, ethnicity, cardiovascular disease, diabetes, smoking, body mass index, systolic blood pressure) were used to estimate the hazard ratios for outcomes associated with estimated glomerular filtration rate, urinary albumin-creatinine ratio, protein-creatinine ratio, and dipstick proteinuria. Analyses 
of the risk association with estimated glomerular filtration rate were adjusted by albuminuria, and vice versa.

For continuous analyses, linear splines of estimated glomerular filtration rate (knots at each $15 \mathrm{~mL} / \mathrm{min} / 1.73 \mathrm{~m}^{2}$ from 30 to 105 (to 90 in chronic kidney disease cohorts)) and their product terms with sex were fitted. Sex-specific reference points were used (estimated glomerular filtration rate of 95 in general and high risk cohorts and 50 in chronic kidney disease cohorts).

From this model, the interaction was evaluated as the ratio of hazard ratios (relative hazard ratio) in women versus men at each $1 \mathrm{~mL} / \mathrm{min} / 1.73 \mathrm{~m}^{2}$ of estimated glomerular filtration rate from 15 to 120 (to 60 in chronic kidney disease cohort) ("pointwise interaction"). To visually assess the main effect of sex on estimates of risk, analyses were repeated using a single reference point of estimated glomerular filtration rate of 95 in women. Because all chronic kidney disease cohorts had mean estimated glomerular filtration rates of $<55$ at baseline (see table $1 \Downarrow$ ), a reference point of 50 was chosen.

A similar approach was used in assessing the risk associations with urinary albumin-creatinine ratio. The albumin-creatinine ratio was log transformed, and linear splines were fitted with knots at 10,30, and $300(30,300,1000$ in chronic kidney disease cohorts), with a reference value at 5 (100 in chronic kidney disease cohorts because many participants had an albumin-creatinine ratio $>30$ ). Pointwise interactions of the risk association of urinary albumin-creatinine ratio with sex were assessed at approximate $8 \%$ increments of the

albumin-creatinine ratio. Categorical analyses were performed using estimated glomerular filtration rate and proteinuria categories as described above. Finally, a summary interaction effect of sex was defined as the inverse variance weighed average of all the individual spline relative hazard ratios for each estimated glomerular filtration rate and urinary albumin-creatinine ratio, separately.

\section{Stage 2: pooled analyses of cohorts}

Random effects meta-analysis was used to pool the individual and summary hazard ratios from all studies. Heterogeneity was estimated by the $\chi^{2}$ test and the $\mathrm{I}^{2}$ statistic. ${ }^{22}$ Given their similar risk associations, the general population and high risk cohorts were combined. Meta-regression, with $\log$ (hazard ratio) regressed on sex, was used to estimate the effect of sex on hazard ratio, comparing any specific level of estimated glomerular filtration rate or albuminuria to reference across all 46 studies, including those conducted among only men. In all analyses, we used $95 \%$ confidence intervals, and a nominal $\mathrm{P}$ value $<0.05$ was deemed significant.

\section{Sensitivity analyses}

We repeated the primary analyses among subgroups defined by: presence or absence of diabetes ${ }^{23}$; body mass index $<30$ or $\geq 30$; age categories $<65$ and $\geq 65$ years; presence or absence of baseline cardiovascular disease; and in presumed premenopausal women (ages $<50$ years) and postmenopausal women (ages $\geq 65$ years). ${ }^{24}$

\section{Results \\ Cohort characteristics}

There were 26 general population cohorts ( $n=1861052)$, seven high risk cohorts ( $n=151494$ plus subsample of the AKDN study with data on albumin-creatinine ratio $(n=102639)$ ), and 13 chronic kidney disease cohorts $(n=38$ 612) (table $1 \Downarrow)$. Cohorts represented a range of geographical areas in Asia, Europe, North and South America, Asia, and Australasia; average mean follow-up was 5.8 years. General population cohorts had 89595 deaths in 10088864 person years follow-up, and high risk and chronic kidney disease cohorts had 13693 and 9019 deaths in 888386 and 149917 person years follow-up, respectively. Only a subset of cohorts had data on cardiovascular death (supplementary table on bmj.com). Overall, women comprised $54 \%$ of the general population cohorts, $50 \%$ of the high risk cohorts, and $47 \%$ of the chronic kidney disease cohorts. Mean age was lower in the general population cohorts (48 years) than the high risk cohorts (56 years) and chronic kidney disease cohorts (68 years), with no obvious sex differences. On average, women had levels of estimated glomerular filtration rate similar to those of men and a slightly lower prevalence of albuminuria (4\% of women and $5 \%$ of men in general population). Fewer women had baseline hypertension, diabetes, cardiovascular disease, hypercholesterolemia, or were smokers (supplementary table).

\section{Sex-specific associations of estimated glomerular filtration rate and albuminuria with all-cause mortality}

In the combined general population and high risk cohorts, men had a $60 \%$ higher risk of all-cause mortality than women at an estimated glomerular filtration rate of 95 (adjusted hazard ratio 1.60 (95\% confidence interval 1.52 to 1.69$)$ ) (fig $1 \mathrm{~A} \Downarrow)$. The adjusted hazard ratio for all-cause mortality increased with lower levels of estimated glomerular filtration rate in both sexes, but the slope of the mortality risk relationship was steeper for women than men (fig 1B). For example, the risk became significant at a higher level of estimated glomerular filtration rate in women than men $(52 v 44)$, and the relative risk was slightly higher in women at glomerular filtration rates of $\leq 56$ (average relative hazard ratio per 15 decrease in estimated glomerular filtration rate comparing women to men, 1.04 (95\% confidence interval 1.02 to 1.07$)$, $\mathrm{P}$ for interaction $<0.01$ ). Compared with a reference estimated glomerular filtration rate of 95 , the adjusted hazard ratio for all-cause mortality at glomerular filtration rate 45 was 1.32 (1.08 to 1.61) in women and 1.22 (1.00 to 1.48 ) in men (fig $2 \Downarrow$ ). Categorical associations for estimated glomerular filtration rate and mortality risk were similar: compared with a reference estimated glomerular filtration rate of 90-104, women with a rate $<45$ had a higher mortality risk than men (table $2 \Downarrow$, last column). The results for estimated glomerular filtration rate showed less heterogeneity among general population cohorts with urinary

albumin-creatinine ratio data $\left(\mathrm{I}^{2}=34.2 \%\right)$ and among high risk cohorts $\left(I^{2}=42.9 \%\right)$ than for the cohorts with urinary dipstick data $\left(I^{2}=84.1 \%\right)$.

Similar patterns were observed in the estimates of all-cause mortality risk associated with albuminuria (fig $1 \Downarrow$, panels $\mathrm{C}$ and D). There was statistical evidence for interaction by sex, with a steeper increase in adjusted hazard ratio among women at urinary albumin-creatinine ratio $>22$ (fig 1D). Compared with a reference of albumin-creatinine ratio of 5 , the adjusted hazard ratio for an albumin-creatinine ratio of 30 was 1.69 (1.54 to 1.84 ) in women and 1.43 (1.31 to 1.57) in men ( $\mathrm{P}$ for interaction $<0.01$ ) (fig $3 \Downarrow$ ). In a categorical analysis combining cohorts measuring dipstick proteinuria, urinary albumin-creatinine ratio, and protein-creatinine ratio, the risk was present in both men and women in the high-normal category compared with normal category; however, women had a higher adjusted hazard ratio than men in each of the three clinical categories (high-normal, mild, and heavy) (table $2 \Downarrow$ ). 
In the chronic kidney disease cohorts, men had a higher adjusted all-cause mortality risk than women (hazard ratio at estimated glomerular filtration rate of 50, 1.28 (1.18 to 1.40)). As with the general population cohorts, lower estimated glomerular filtration rate and higher albuminuria were associated with increased all-cause mortality in both sexes (supplementary fig 1, panels A and C, on bmj.com). Unlike the general population cohorts, however, the pointwise interaction terms were not significant at lower levels of estimated glomerular filtration rate (supplementary fig 1, B), nor was there a significant interaction in upper levels of urinary albumin-creatinine ratio (supplementary fig 1, D).

\section{Sex-specific associations of estimated glomerular filtration rate and albuminuria with cardiovascular mortality}

In the combined general population and high risk cohorts, men had higher cardiovascular mortality at all levels of estimated glomerular filtration rate (adjusted hazard ratio at estimated glomerular filtration rate of 95, 1.66 (1.48 to 1.86)) (see supplementary fig 2, A). Similarly, a higher cardiovascular risk was seen for men in the chronic kidney disease cohorts (supplementary fig 3, A). As with all-cause mortality, the cardiovascular mortality risk relationship was steeper for women than men. For example, reduction of estimated glomerular filtration rate by 15 was associated with a $6 \%$ higher cardiovascular risk among women when compared with same association among men (average relative hazard ratio of women $v$ men, 1.06 (1.02 to 1.09)), with minimal heterogeneity between cohorts $\left(\mathrm{I}^{2}=5.4 \%\right)$. In categorical analysis, an increase in cardiovascular risk was apparent for the estimated glomerular filtration rate category of 75-89 among women (hazard ratio 1.11 (1.02 to 1.21$)$ ) but not men (hazard ratio 1.02 (0.95 to 1.10)). Significant interactions (with higher hazard ratios among women compared with those among men) were found for all categories of estimated glomerular filtration rate between 15 and 60 (table $2 \Downarrow$ ).

Higher levels of urinary albumin-creatinine ratio were associated with increased cardiovascular risk in the combined general population and high risk cohorts (supplementary fig 2, C and D). The slope of the risk relationship was significantly steeper in women than in men. For example, a 10-fold increase of urinary albumin-creatinine ratio was associated with an $18 \%$ higher cardiovascular risk among women (average relative hazard ratio of women $v$ men 1.18 (1.02 to 1.36)), with mild heterogeneity between cohorts $\left(I^{2}=32.3 \%\right)$. Categorical analysis showed similar associations (table $2 \Downarrow$ ).

While the overall pattern of association of estimated glomerular filtration rate with cardiovascular mortality was similar in the chronic kidney disease cohorts, this analysis was based on only 896 cardiovascular deaths (supplementary table on bmj.com). Confidence intervals were wide (supplementary fig 3, A), and there was no evidence of an interaction by sex (supplementary fig 3, B). The adjusted association of urinary albumin-creatinine ratio with cardiovascular mortality seemed flat for both men and women with wide confidence intervals (supplementary fig 3, C and D).

\section{Sex-specific associations of estimated glomerular filtration rate and urinary albumin-creatinine ratio with end stage renal disease}

Results are shown for the chronic kidney disease cohorts, which provided $71 \%(\mathrm{n}=5960)$ of all observed instances of end stage renal disease ( $\mathrm{n}=8409$ ) (fig $4 \Downarrow$ ). Lower estimated glomerular filtration rate and higher urinary albumin-creatinine ratio were associated with increased risk of end stage renal disease in both sexes (fig 4A and 4C). The associations of estimated glomerular filtration rate with end stage renal disease overlapped for men and women, with limited evidence for interaction ( $\mathrm{P}$ for interaction=0.27) (fig 4B). For urinary albumin-creatinine ratios between 15 and 350, women showed a slightly steeper risk relationship with end stage renal disease than men (fig 4D). For example, compared with a urinary albumin-creatinine ratio of 100 , the hazard ratio associated with a ratio of 300 was 1.63 (1.33 to 1.99$)$ in women and 1.33 (1.04 to 1.69) in men (P for interaction $<0.01)$. There was heterogeneity in the association with end stage renal disease of estimated glomerular filtration rate $\left(\mathrm{I}^{2}=70 \%\right)$ but not in that of the urinary albumin-creatinine ratio $\left(\mathrm{I}^{2}=0 \%\right)$.

Results were similar in the general population and high risk cohorts. Lower estimated glomerular filtration rate and higher urinary albumin-creatinine ratio were associated with higher risk of end stage renal disease (supplementary fig 4, A and C, on bmj.com), with no evidence for sex-specific associations (supplementary fig 4, B and D).

\section{Sensitivity analyses}

There was no evidence for modification of the sex interaction by diabetes, age, obesity (data not shown), or when grouped into presumed premenopausal ( $<50$ years old) and postmenopausal age ( $\geq 65$ years old). In the general population and high risk cohorts, the associations of estimated glomerular filtration rate with all-cause mortality and cardiovascular mortality were more "U shaped" (with higher risk in levels of estimated glomerular filtration rate $>95$ ) in the older age group ( $\geq 65$ years old) than in the younger age groups (supplementary figs 5 and 6). Nevertheless, in both age groups the estimated glomerular filtration rate cut-off at which estimated glomerular filtration rate reached statistical significance was higher amongst women than men. In meta-regression, including the two studies comprised solely of men did not materially change results.

When stratified by age, the point estimate of the risk relationship between urinary albumin-creatinine ratio and all-cause mortality implied a steeper association for women than men (age $<65$ years, relative hazard ratio 1.03 ( 0.98 to 1.08 ; age $\geq 65$ years, relative hazard ratio 1.05 (1.02 to 1.09$)$ ), similar to the association of urinary albumin-creatinine ratio with cardiovascular mortality ( $<65$ years, relative hazard ratio 1.09 (0.95 to 1.23 ); $\geq 65$ years, relative hazard ratio 1.08 (1.00 to 1.14)).

\section{Discussion}

In this pooled analysis of over two million participants in 33 general population and high cardiovascular risk cohorts, men had a higher risk than women for all-cause mortality and cardiovascular mortality at all levels of kidney function. However, the risk relationships of reduced estimated glomerular filtration rate and higher albuminuria with mortality were steeper in women than they were in men; thus, the mortality risk associated with chronic kidney disease was at least as great among women. These results strongly refute the idea that lower estimated glomerular filtration rate and higher albuminuria are less important risk factors in women than in men. Modification of mortality risk by gender was not seen in the 13 chronic kidney disease cohorts ( $n=38612$ ), where even the main effect of sex was attenuated. The risk of progression to end stage renal disease 
at a given estimated glomerular filtration rate and urinary albumin-creatinine ratio seemed equivalent in men and women.

\section{Strengths and limitations of study}

Our study has several strengths, including an international consortium, comprehensive data on estimated glomerular filtration rate and albuminuria, and a large pooled study size. The data represent a wide range of cohorts in various settings, and thus our findings may apply to a wide range of clinical and general care settings. Our analysis was centrally coordinated, and adjustment for important variables was carried out in all cohorts. Our continuous analysis using splines allowed visualisation of the association curves across the entire range of urinary albumin-creatinine ratios and estimated glomerular filtration rates.

Our study also has recognised limitations. There were no studies from the African continent, and only few black participants.

The analysis was based on serum creatinine measurements and urine albumin-creatinine ratio at a single time point.

Albuminuria is associated with smoking, high body mass index, diabetes, and high blood pressure, and thus the variability of albuminuria prevalence across high risk cohorts is, in part, explained by the cardiovascular risk profile of the study participants at baseline. All analyses have adjusted for albuminuria and cardiovascular risk factors at baseline. Not all assays were uniform, but every attempt was made to make chronic kidney disease measures comparable across studies (appendix 2 on bmj.com). As in all observational studies, residual confounding is possible, and we were unable to adjust for several potential confounders, including $\mathrm{C}$ reactive protein, serum albumin, socioeconomic status, and physical activity. However, given the strength of the associations observed, it is unlikely that residual confounding would negate our results.

Some of the observed heterogeneity may be due to differences in follow-up and outcome ascertainment. Causes of death may differ between men and women, and not all causes of death are associated with chronic kidney disease (for example, accidents and certain infections $\mathrm{s}^{25}$ ), which may explain the heterogeneity in all-cause mortality. In general population cohorts with available causes of deaths, about a third of deaths were cardiovascular. There was much less heterogeneity in the cardiovascular mortality associations than the all-cause mortality associations, which was otherwise broadly similar to those for all-cause mortality.

\section{Comparison with other studies and implications}

Our results contrast with previous studies suggesting that the association of estimated glomerular filtration rate with mortality is equivalent or weaker in women. ${ }^{26-28}$ Variations in the underlying populations studied may explain some of the difference: the NHANES study follows a US cohort, ${ }^{27}$ and the MRC study enrolled only people aged $\geq 75$ years $^{28}$; and all estimated glomerular filtration rate by means of the Modification of Diet in Renal Disease (MDRD) Study equation, which may have resulted in misclassification of women with an estimated glomerular filtration rate of $45-59 .{ }^{29}$ Recent studies have demonstrated the superiority of the Chronic Kidney Disease Epidemiology Collaboration equation for estimating measured glomerular filtration rate and for predicting prognosis. ${ }^{11} 123031$ In addition, the reference groups used in the previous studies were different from the ones used here. The choice of reference can affect the estimation of interaction: choosing an estimated glomerular filtration rate $>60$, for example, assumes the same risk across the range of reference estimated glomerular filtration rate, and may blunt estimates of associations (particularly when associations are U shaped).

Some investigators have suggested different thresholds of estimated glomerular filtration rate for defining chronic kidney disease in men and women, where "normal" kidney function encompasses a lower glomerular filtration rate in women than men. ${ }^{32}{ }^{33}$ Our results strongly contradict this assertion: the risk relationship increases more steeply at lower levels of glomerular filtration rate for women than for men. We also found a smaller increase in mortality risk at higher estimated glomerular filtration rate in women than in men. Previous studies have suggested that the increased mortality at higher estimated glomerular filtration rate (resulting in a $U$ shaped association between glomerular filtration rate and mortality) may be attributable to frailty or low muscle mass leading to decreased creatinine generation rather than high levels of kidney function. ${ }^{11}{ }^{32}$ Our findings suggest some sex differences in the relation of frailty or muscle mass with kidney function and mortality. It was reassuring to see that the associations of mortality and of end stage renal disease with estimated glomerular filtration rate were linear in the chronic kidney disease cohorts and among the younger participants in the general population and high risk cohorts.

Similarly, because of the generally greater concentration of urine creatinine in men, sex-specific cut points to define pathological albuminuria have been proposed. ${ }^{34} \mathrm{We}$ found a stronger association between albuminuria and mortality risk (all-cause and cardiovascular) in women than men, both in the studies measuring urinary albumin-creatinine ratio and those measuring dipstick proteinuria (which is not corrected for urine creatinine). Our results are in line with a previous study ${ }^{35}$ and do not support higher thresholds for urinary albumin-creatinine ratio in women.

It is well accepted that men face a higher baseline cardiovascular risk than women. ${ }^{16}$ The reason for this is not clear, nor for our finding that this difference narrows at lower levels of estimated glomerular filtration rate and higher levels of albuminuria. Speculations as to possible explanations include differences between men and women in onset, duration, and severity of some risk factors, including diabetes, hypertension, obesity, and smoking. The observed steeper associations of chronic kidney disease with mortality risk among women may reflect more advanced microvascular disease in women and relatively lower macrovascular disease and its consequent mortality in women, ${ }^{16}$ or potential complacency in the treatment and prevention of vascular disease among women. Women experience increased early mortality after acute myocardial infarction compared with men, ${ }^{36}{ }^{37}$ particularly in younger age groups, ${ }^{38}{ }^{39}$ a trend some attribute to delays in or lack of administration of reperfusion therapy ${ }^{38}$ or drugs used in secondary prevention. ${ }^{40}$ Similar issues of provider complacency may pertain in chronic kidney disease in the general population.

We did not find a difference between the sexes in mortality associations within the chronic kidney disease cohorts. This may be due to selection biases ${ }^{41}{ }^{42}$ (that is, women with chronic kidney disease dying before referral or being referred later than men), or renal care being more equal for women and men than within primary care. More simply, the choice of reference may explain why an interaction was not seen in the chronic kidney disease cohorts. The fundamental question tested differs: in the general population cohorts, we asked whether the risk of mortality associated with reduced estimated glomerular filtration rate (or higher urinary albumin-creatinine ratio) compared with normal kidney function differed between men and women. In the chronic kidney disease cohorts, our comparison group 
comprised those already experiencing reduced kidney function (estimated glomerular filtration rate 50 or urinary albumin-creatinine ratio 100). While there seems to be a sex difference in risk associated with chronic kidney disease when compared with normal kidney function, risk associated with further reductions in estimated glomerular filtration rate (or increases in urinary albumin-creatinine ratio) for a person already afflicted with chronic kidney disease may not differ by sex.

In both the general population and chronic kidney disease cohorts, there was no difference by sex in the risk of end stage renal disease associated with albuminuria or reduced estimated glomerular filtration rate. Future research is needed to determine why the incidence of renal replacement therapy in men exceeds that in women. ${ }^{13}{ }^{14}$ One potential explanation could be that in our study fewer women had albuminuria, although the prevalence of reduced estimated glomerular filtration rate (as measured by the Chronic Kidney Disease Epidemiology Collaboration equation) was similar by sex. Another possible explanation could be competing mortality. We found stronger associations of urinary albumin-creatinine ratio with all-cause and cardiovascular mortality among women than men. The hazard ratio associated with end stage renal disease does not take into account the possibility of unequal rates of mortality by sex. We had too few cohorts with both mortality data and end stage renal disease events to investigate this issue further.

\section{Conclusions}

In this pooled analysis of over two million participants, there was an increased risk of all-cause and cardiovascular mortality and end stage renal disease with lower estimated glomerular filtration rate and higher albuminuria in both sexes. In stark contrast to previous assertions that kidney disease should be defined by a lower threshold for estimated glomerular filtration rate and higher threshold for urinary albumin-creatinine ratio in women, we found the association between chronic kidney disease and mortality risk to be as strong in women as in men. Low estimated glomerular filtration rate or albuminuria should be considered at least as potent a risk factor in women as it is in men.

\section{The Chronic Kidney Disease Prognosis Consortium (CKD-PC)} investigators and collaborators: AASK-Jackson Wright, Lawrence Appel, Tom Greene, Brad C Astor; ADVANCE-John Chalmers, Stephen MacMahon, Mark Woodward, Hisatomi Arima; Aichi-Hiroshi Yatsuya, Kentaro Yamashita, Hideaki Toyoshima, Koji Tamakoshi;

AKDN—Marcello Tonelli, Brenda Hemmelgarn, Aminu Bello, Matt James; ARIC_Josef Coresh, Brad C Astor, Kunihiro Matsushita, Yingying Sang; AusDiab-Robert C Atkins, Kevan R Polkinghorne, Steven Chadban; Beaver Dam CKD—Anoop Shankar, Ronald Klein, Barbara EK Klein, Kristine E Lee; Beijing Cohort-Haiyan Wang, Fang Wang, Luxia Zhang, Li Zuo; British Columbia CKD—Adeera Levin, Ognjenka Djurdjev; CARE-Marcello Tonelli, Frank M Sacks, Gary C Curhan; CHS-Michael Shlipak, Carmen Peralta, Ronit Katz, Linda Fried; CIRCS—Hiroyasu Iso, Akihiko Kitamura, Tetsuya Ohira, Kazumasa Yamagishi; COBRA-Tazeen H Jafar, Muhammad Islam, Juanita Hatcher, Neil Poulter, Nish Chaturvedi; CRIB-Martin J Landray, Jonathan Emberson, John N Townend, David C Wheeler; ESTHER—Dietrich Rothenbacher, Hermann Brenner, Heiko Müller, Ben Schöttker; Framingham—Caroline S Fox, Shih-Jen Hwang, James B Meigs; Geisinger-Robert M Perkins; GLOMMS-1 Study—Nick Fluck, Laura E Clark, Gordon J Prescott, Angharad Marks, Corri Black; Gubbio-Massimo Cirillo; HUNT—Stein Hallan, Knut Aasarød, Cecilia M Øien, Marie Radtke; IPHS—Fujiko Irie, Hiroyasu Iso, Toshimi Sairenchi, Kazumasa Yamagishi; Kaiser Permanente NW—David H Smith, Jessica W Weiss, Eric S Johnson,
Micah L Thorp; KEEP—Allan J Collins, Joseph A Vassalotti, Suying Li, Shu-Cheng Chen; KP Hawaii-Brian J Lee; MASTERPLAN-Jack F Wetzels, Peter J Blankestijn, Arjan D van Zuilen; MDRD—Mark Sarnak, Andrew S Levey, Vandana Menon; MESA—Michael Shlipak, Mark Sarnak, Carmen Peralta, Ronit Katz, Holly J Kramer, lan H de Boer; MMKD—Florian Kronenberg, Barbara Kollerits, Eberhard Ritz; MRC Older People-Paul Roderick, Dorothea Nitsch, Astrid Fletcher, Christopher Bulpitt; MRFIT—Areef Ishani, James D Neaton; NephroTest-Marc Froissart, Benedicte Stengel, Marie Metzger, Jean-Philippe Haymann, Pascal Houillier, Martin Flamant; NHANES III-Brad C Astor, Josef Coresh, Kunihiro Matsushita;

Ohasama-Takayoshi Ohkubo, Hirohito Metoki, Masaaki Nakayama, Masahiro Kikuya, Yutaka Imai; Okinawa 83/93-Kunitoshi Iseki; Pima Indian-Robert G Nelson, William C Knowler; PREVEND—Ron T Gansevoort, Paul E de Jong, Bakhtawar K Mahmoodi, Hans Hillege; Rancho Bernardo-Simerjot Kaur Jassal, Elizabeth Barrett-Connor, Jaclyn Bergstrom; RENAAL—Hiddo J Lambers Heerspink, Barry E Brenner, Dick de Zeeuw; Renal REGARDS—David G Warnock, Paul Muntner, Suzanne Judd, William McClellan; Severance-Sun Ha Jee, Heejin Kimm, Jaeseong Jo, Yejin Mok, Eunmi Choi; STENO—Peter Rossing, Hans-Henrik Parving; Sunnybrook—Navdeep Tangri, David Naimark; Taiwan GP_Chi-Pang Wen, Sung-Feng Wen, Chwen-Keng Tsao, Min-Kuang Tsai; ULSAM—Johan Ärnlöv, Lars Lannfelt, Anders Larsson; ZODIAC—Henk J Bilo, Hanneke Joosten, Nanno Kleefstra, Klaas $\mathrm{H}$ Groenier, lefke Drion.

CKD-PC Steering Committee: Brad C Astor, Josef Coresh (chair), Ron T Gansevoort, Brenda R Hemmelgarn, Paul E de Jong, Andrew S Levey, Adeera Levin, Kunihiro Matsushita, Chi-Pang Wen, Mark Woodward.

CKD-PC Data Coordinating Center: Shoshana H Ballew (coordinator), Josef Coresh (principal investigator), Morgan Grams, Bakhtawar K Mahmoodi, Kunihiro Matsushita (director), Yingying Sang (lead programmer), Mark Woodward (senior statistician); Administrative support: Laura Camarata, Xuan Hui, Jennifer Seltzer, Heather Winegrad. Contributors: All authors had full access to the analysis reports and tables and take responsibility for the integrity of the data and the accuracy of the data analysis. The CKD-PC contributed to all aspects of the study. Conception and design: DN, MG, BRH, ASL. Analysis and interpretation of the data: DN, MG, YS, MW, BRH. Critical revision of the article for important intellectual content, and final approval of the article: all authors. Statistical expertise: YS, MW. Obtaining of funding: $\mathrm{J}$ Coresh for the CKD Prognosis Consortium. Administrative, technical, or logistic support: MG, YS. Collection and assembly of data: YS.

Funding: The CKD-PC Data Coordinating Center is funded in part by a programme grant from the US National Kidney Foundation (NKF funding sources include Abbott) and an investigator initiated research grant from Amgen. Various sources have supported enrolment and data collection including laboratory measurements, and follow-up in the collaborating cohorts of the CKD-PC, including government agencies such as national institutes of health and medical research councils as well as foundations and industry sponsors listed in appendix 3 on bmj.com. The funders had no role in the design, analysis, interpretation of this study, and did not contribute to the writing of this report and the decision to submit the article for publication.

Competing interests: All authors have completed the Unified Competing Interest form at www.icmje.org/coi_disclosure.pdf (available on request from the corresponding author) and declare financial support for the submitted work from the Scottish Chief Scientist office (CB) and CKD-PC/the National Kidney Foundation for data extraction (CB) and travel to research related meetings (ASL, DN); ASL has grants pending with the National Kidney Foundation, and $\mathrm{NIH}$; FK received a research grant for the ARO consortium from Amgen and speaker honoraria from Genzyme; No other relationships or activities that could appear to have influenced the submitted work. 


\section{What is already known on this topic}

Reduced estimated glomerular filtration rate and albuminuria are both independently associated with an increased risk of all-cause mortality and cardiovascular mortality and progression to end stage renal disease

In the US and the UK, women have lower incident rates of starting dialysis than men

\section{What this study adds}

Using data from a global consortium of cohort studies, we found that the risks for mortality were higher in men than in women at all levels of estimated glomerular filtration rate and albuminuria. However, the slope of the associations with lower estimated glomerular filtration rate and higher albuminuria were steeper for women than men

Thus, compared with normal levels of estimated glomerular filtration rate and urinary albumin-creatinine ratio, the mortality risk associated with chronic kidney disease was slightly higher in women than men

The risk for end stage renal disease at a given estimated glomerular filtration rate and urinary albumin-creatinine ratio was equivalent between men and women

Data sharing: CKD-PC has agreed with collaborating cohorts not to share data outside the consortium. Each participating cohort has its own policy for data sharing.

1 Perkovic V, Cass A, Patel AA, Suriyawongpaisal P, Barzi F, Chadban S, et al. High prevalence of chronic kidney disease in Thailand. Kidney Int 2008;73:473-9.

2 Wen CP, Cheng TY, Tsai MK, Chang YC, Chan HT, Tsai SP, et al. All-cause mortality attributable to chronic kidney disease: a prospective cohort study based on 462293 adults in Taiwan. Lancet 2008;371:2173-82.

3 Chadban SJ, Briganti EM, Kerr PG, Dunstan DW, Welborn TA, Zimmet PZ, et al. Prevalence of kidney damage in Australian adults: The AusDiab kidney study. J Am Soc Nephrol 2003;14(7 suppl 2):S131-8.

4 Hallan SI, Dahl K, Oien CM, Grootendorst DC, Aasberg A, Holmen J, et al. Screening strategies for chronic kidney disease in the general population: follow-up of cross sectional health survey. BMJ 2006;333:1047.

5 Verhave JC, Hillege HL, Burgerhof JG, Gansevoort RT, de Zeeuw D, de Jong PE. The association between atherosclerotic risk factors and renal function in the general population. Kidney Int 2005;67:1967-73.

6 Nitsch D, Felber Dietrich D, von Eckardstein A, Gaspoz JM, Downs SH, Leuenberger P, et al. Prevalence of renal impairment and its association with cardiovascular risk factors in a general population: results of the Swiss SAPALDIA study. Nephrol Dial Transplant 2006;21:935-44.

7 Astor BC, Matsushita K, Gansevoort RT, van der Velde M, Woodward M, Levey AS, et al. Lower estimated glomerular filtration rate and higher albuminuria are associated with mortality and end-stage renal disease. A collaborative meta-analysis of kidney disease population cohorts. Kidney Int 2011;79:1331-40.

8 Matsushita K, van der Velde M, Astor BC, Woodward M, Levey AS, de Jong PE, et al. Association of estimated glomerular filtration rate and albuminuria with all-cause and cardiovascular mortality in general population cohorts: a collaborative meta-analysis. Lancet 2010;375:2073-81.

9 Gansevoort RT, Matsushita K, van der Velde M, Astor BC, Woodward M, Levey AS, et al. Lower estimated GFR and higher albuminuria are associated with adverse kidney outcomes in both general and high-risk populations. A collaborative meta-analysis of general and high-risk population cohorts. Kidney Int 2011;80:93-104.

10 Go AS, Chertow GM, Fan D, McCulloch CE, Hsu CY. Chronic kidney disease and the risks of death, cardiovascular events, and hospitalization. $N$ Engl $J \mathrm{Med}$ 2004;351:1296-305.

11 Matsushita K, Mahmoodi BK, Woodward M, Emberson JR, Jafar TH, Jee SH, et al. Comparison of risk prediction using the CKD-EPI equation and the MDRD study equation for estimated glomerular filtration rate. JAMA 2012;307:1941-51

12 Levey AS, Stevens LA, Schmid CH, Zhang YL, Castro AF 3rd, Feldman HI, et al. A new equation to estimate glomerular filtration rate. Ann Intern Med 2009;150:604-12.

13 Van Dijk PC, Zwinderman AH, Dekker FW, Schon S, Stel VS, Finne P, et al. Effect of general population mortality on the north-south mortality gradient in patients on replacement therapy in Europe. Kidney Int 2007;71:53-9.

14 US Renal Data System. USRDS 2010 annual data report: atlas of chronic kidney disease and end-stage renal disease in the United States. National Institutes of Health, Nationa Institute of Diabetes and Digestive and Kidney Diseases, 2010. www.usrds.org/atlas10. aspx.

15 Pilote L, Dasgupta K, Guru V, Humphries KH, McGrath J, Norris C, et al. A comprehensive view of sex-specific issues related to cardiovascular disease. CMAJ 2007;176:S1-44.

16 World Health Organization. Women and health: today's evidence tomorrow's agenda. WHO Press, 2009. http://whqlibdoc.who.int/publications/2009/9789241563857_eng.pdf.

17 Levey AS, de Jong PE, Coresh J, Nahas ME, Astor BC, Matsushita K, et al. The definition, classification, and prognosis of chronic kidney disease: a KDIGO Controversies Conference report. Kidney Int 2011;80:17-28.

18 National Kidney Foundation. K/DOQI clinical practice guidelines for chronic kidney disease: evaluation, classification, and stratification. Am J Kidney Dis 2002:39(2 suppl 1):S1-266.

19 National Institute for Health and Clinical Excellence. Chronic kidney disease: Early identification and management of chronic kidney disease in adults in primary and secondary care. NICE, 2008. www.nice.org.uk/CG73.

20 Levey AS, Stevens LA. Estimating GFR using the CKD Epidemiology Collaboration (CKD-EPI) creatinine equation: more accurate GFR estimates, lower CKD prevalence estimates, and better risk predictions. Am J Kidney Dis 2010;55:622-7.

21 Levey AS, Eckardt KU, Tsukamoto Y, Levin A, Coresh J, Rossert J, et al. Definition and classification of chronic kidney disease: a position statement from Kidney Disease: Improving Global Outcomes (KDIGO). Kidney Int 2005;67:2089-100.

22 Woodward M. Epidemiology: study design and data analysis . 2nd ed. Chapman \& Hall/CRC, 2005
23 Huxley R, Barzi F, Woodward M. Excess risk of fatal coronary heart disease associated with diabetes in men and women: meta-analysis of 37 prospective cohort studies. BMJ 2006;332:73-8.

24 Guthrie JR, Dennerstein L, Taffe JR, Lehert P, Burger HG. The menopausal transition: a 9-year prospective population-based study. The Melbourne Women's Midlife Health Project. Climacteric 2004;7:375-89.

25 James MT, Quan H, Tonelli M, Manns BJ, Faris P, Laupland KB, et al. CKD and risk of hospitalization and death with pneumonia. Am J Kidney Dis 2009;54:24-32.

26 Kurth T, de Jong PE, Cook NR, Buring JE, Ridker PM. Kidney function and risk of cardiovascular disease and mortality in women: a prospective cohort study. $B M J$ 2009;338:b2392

27 Muntner P, He J, Hamm L, Loria C, Whelton PK. Renal insufficiency and subsequent death resulting from cardiovascular disease in the United States. J Am Soc Nephrol 2002;13:745-53.

28 Roderick PJ, Atkins RJ, Smeeth L, Mylne A, Nitsch DD, Hubbard RB, et al. CKD and mortality risk in older people: a community-based population study in the United Kingdom. Am J Kidney Dis 2009;53:950-60.

29 Froissart M, Rossert J, Jacquot C, Paillard M, Houillier P. Predictive performance of the modification of diet in renal disease and Cockcroft-Gault equations for estimating renal function. J Am Soc Nephrol 2005;16:763-73.

30 Earley A, Miskulin D, Lamb EJ, Levey AS, Uhlig K. Estimating equations for glomerular filtration rate in the era of creatinine standardization: a systematic review. Ann Intern Med 2012;156:785-95.

31 Matsushita K, Selvin E, Bash LD, Astor BC, Coresh J. Risk implications of the new CKD Epidemiology Collaboration (CKD-EPI) equation compared with the MDRD Study equation for estimated GFR: the Atherosclerosis Risk in Communities (ARIC) Study. Am J Kidney Dis 2010;55:648-59.

32 Glassock RJ, Winearls C. Screening for CKD with eGFR: doubts and dangers. Clin J Am Soc Nephrol 2008;3:1563-8.

33 Wetzels JF, Kiemeney LA, Swinkels DW, Willems HL, den Heijer M. Age- and gender-specific reference values of estimated GFR in Caucasians: the Nijmegen Biomedical Study. Kidney Int 2007;72:632-7.

34 IDF Clinical Guidelines Task Force. Chapter 14: Kidney damage. In: Global guideline for type 2 diabetes. International Diabetes Federation, 2005. www.idf.org/webdata/docs/ GGT2D\%2014\%20Kidney\%20damade.pdt

35 Jassal SK, Langenberg C, von Muhlen D, Bergstrom J, Barrett-Connor E. Usefulness of microalbuminuria versus the metabolic syndrome as a predictor of cardiovascular disease in women and men>40 years of age (from the Rancho Bernardo Study). Am J Cardiol 2008;101:1275-80

36 Weaver WD, White HD, Wilcox RG, Aylward PE, Morris D, Guerci A, et al. Comparisons of characteristics and outcomes among women and men with acute myocardial infarction treated with thrombolytic therapy. GUSTO-I investigators. JAMA 1996;275:777-82.

37 Jneid H, Fonarow GC, Cannon CP, Hernandez AF, Palacios IF, Maree AO, et al. Sex differences in medical care and early death after acute myocardial infarction. Circulation 2008;118:2803-10

38 Vaccarino V, Parsons L, Every NR, Barron HV, Krumholz HM. Sex-based differences in early mortality after myocardial infarction. National Registry of Myocardial Infarction 2 Participants. N Engl J Med 1999;341:217-25.

39 Vaccarino V, Krumholz HM, Yarzebski J, Gore JM, Goldberg RJ. Sex differences in 2-year mortality after hospital discharge for myocardial infarction. Ann Intern Med 2001;134:173-81

40 Lee HY, Cooke CE, Robertson TA. Use of secondary prevention drug therapy in patients with acute coronary syndrome after hospital discharge. J Manag Care Pharm 2008;14:271-80.

41 Hemmelgarn BR, Zhang J, Manns BJ, James MT, Quinn RR, Ravani P, et al. Nephrology visits and health care resource use before and after reporting estimated glomerular filtration rate. JAMA 2010;303:1151-8.

42 Richards N, Harris K, Whitfield M, O'Donoghue D, Lewis R, Mansell M, et al. The impact of population-based identification of chronic kidney disease using estimated glomerular filtration rate (eGFR) reporting. Nephrol Dial Transplant 2008;23:556-61.

\section{Accepted: 28 December 2012}

\section{Cite this as: BMJ 2013;346:f324}

This is an open-access article distributed under the terms of the Creative Commons Attribution Non-commercial License, which permits use, distribution, and reproduction in any medium, provided the original work is properly cited, the use is non commercial and is otherwise in compliance with the license. See: http://creativecommons.org/licenses/by$\mathrm{nc} / 2.0 /$ and http://creativecommons.org/licenses/by-nc/2.0/legalcode. 


\section{Tables}

Table 1| Descriptive characteristics of cohorts included in meta-analysis of sex-specific associations of chronic kidney disease with mortality and end stage renal disease. Results for men and women are separated by a solidus unless stated otherwise

\begin{tabular}{|c|c|c|c|c|c|c|c|}
\hline \multirow[b]{2}{*}{ Study } & \multirow[b]{2}{*}{ Region } & \multirow[b]{2}{*}{$\begin{array}{l}\text { No of participants } \\
\text { (\% women) }\end{array}$} & \multicolumn{5}{|c|}{ Men/women } \\
\hline & & & Mean (SD) age (years) & $\begin{array}{c}\% \text { with } \\
\text { diabetes }\end{array}$ & $\begin{array}{c}\% \text { with } \\
\text { hypertension }\end{array}$ & Mean (SD) eGFR & $\begin{array}{c}\text { \% with } \\
\text { albuminuria* }\end{array}$ \\
\hline \multicolumn{8}{|c|}{ General population cohorts } \\
\hline Aichi & Japan & $4731(20)$ & $49(7) / 47(7)$ & $7 / 3$ & $28 / 16$ & $96(14) / 102(14)$ & $3 / 1$ \\
\hline AKDN (Dip) & Canada & $920686(56)$ & $50(16) / 48(17)$ & $9 / 6$ & $23 / 21$ & $84(19) / 86(21)$ & $5 / 4$ \\
\hline ARIC† & USA & $11441(56)$ & $63(6) / 62(6)$ & $18 / 16$ & $46 / 49$ & $84(15) / 85(16)$ & $9 / 8$ \\
\hline AusDiabt & Australia & $11179(55)$ & $52(14) / 51(15)$ & $10 / 7$ & $36 / 29$ & $86(16) / 86(18)$ & $7 / 7$ \\
\hline $\begin{array}{l}\text { Beaver Dam CKD } \\
\text { Study }\end{array}$ & USA & $4857(56)$ & $61(11) / 63(11)$ & $10 / 10$ & $50 / 51$ & $81(17) / 78(19)$ & $6 / 3$ \\
\hline Beijingt & China & $1559(50)$ & $62(9) / 58(10)$ & $29 / 27$ & $60 / 52$ & $83(14) / 83(15)$ & $5 / 6$ \\
\hline CHSt & USA & $2988(59)$ & $78(5) / 78(5)$ & $18 / 14$ & $58 / 67$ & $73(18) / 75(17)$ & $24 / 18$ \\
\hline CIRCS & Japan & $11871(61)$ & $54(9) / 54(9)$ & $7 / 3$ & $41 / 33$ & $89(14) / 89(15)$ & $4 / 2$ \\
\hline COBRA† & Pakistan & $2872(52)$ & $52(11) / 51(11)$ & $19 / 23$ & $35 / 52$ & $101(17) / 105(18)$ & $9 / 10$ \\
\hline ESTHER & Germany & $9641(55)$ & $62(7) / 62(7)$ & $22 / 17$ & $62 / 58$ & $85(20) / 83(20)$ & $15 / 9$ \\
\hline Framingham $†$ & USA & $2956(53)$ & $59(10) / 58(10)$ & $12 / 8$ & $43 / 37$ & $88(19) / 88(18)$ & $11 / 13$ \\
\hline Gubbio† & Italy & $1681(55)$ & $54(6) / 55(6)$ & $7 / 4$ & $39 / 40$ & $89(10) / 81(11)$ & $3 / 5$ \\
\hline HUNT† & Norway & $9659(55)$ & $61(14) / 63(15)$ & $19 / 16$ & $83 / 82$ & $87(19) / 84(20)$ & $15 / 10$ \\
\hline IPHS & Japan & 95451 (66) & $61(10) / 58(10)$ & $8 / 4$ & $56 / 46$ & $85(13) / 86(14)$ & $3 / 2$ \\
\hline MESA $†$ & USA & $6733(53)$ & $62(10) / 62(10)$ & $14 / 11$ & $43 / 47$ & $83(16) / 82(17)$ & $10 / 9$ \\
\hline MRC & UK & $12371(61)$ & $81(4) / 81(5)$ & $10 / 7$ & $72 / 79$ & $60(14) / 55(15)$ & $9 / 7$ \\
\hline NHANES III† & USA & $15563(53)$ & $47(20) / 46(19)$ & $12 / 11$ & $30 / 28$ & $98(24) / 102(25)$ & $11 / 12$ \\
\hline Ohasama & Japan & $1956(64)$ & $65(10) / 62(10)$ & $10 / 10$ & $46 / 37$ & $84(14) / 83(13)$ & $10 / 6$ \\
\hline Okinawa83 & Japan & $9599(60)$ & $47(15) / 54(16)$ & NA/NA & NA/NA & $79(16) / 73(17)$ & $21 / 20$ \\
\hline Okinawa93 & Japan & $93216(57)$ & $53(16) / 56(15)$ & NA/NA & NA/NA & $79(16) / 76(18)$ & $4 / 3$ \\
\hline PREVEND $\dagger$ & Netherlands & $8385(50)$ & $50(13) / 48(12)$ & $4 / 3$ & $39 / 27$ & $90(16) / 87(15)$ & $13 / 10$ \\
\hline RanchoBernardo $†$ & USA & $1474(60)$ & $70(11) / 71(12)$ & $15 / 10$ & $54 / 56$ & $74(16) / 73(18)$ & $13 / 16$ \\
\hline REGARDS $\uparrow$ & USA & $27306(54)$ & $66(9) / 64(9)$ & $22 / 20$ & $58 / 60$ & $84(19) / 86(21)$ & $17 / 14$ \\
\hline Severance & Korea & 76201 (49) & $45(12) / 46(12)$ & $7 / 5$ & $26 / 24$ & $88(14) / 92(15)$ & $7 / 4$ \\
\hline ULSAM + & Sweden & $1103(0)$ & $71(1) / \mathrm{NA}$ & $19 / \mathrm{NA}$ & 75/NA & 76 (11)/NA & $16 / \mathrm{NA}$ \\
\hline Taiwan & Taiwan & $515573(50)$ & $41(14) / 42(14)$ & $5 / 5$ & $18 / 16$ & $90(17) / 96(18)$ & $2 / 2$ \\
\hline $\begin{array}{l}\text { General population } \\
\text { total }\end{array}$ & & 1861052 (54) & $48 / 48$ & $8 / 6$ & $25 / 24$ & $86 / 88$ & $5 / 4$ \\
\hline
\end{tabular}

High cardiovascular risk cohorts

\begin{tabular}{|c|c|c|c|c|c|c|c|}
\hline ADVANCE $\dagger$ & Multipleף & $10595(42)$ & $66(7) / 66(6)$ & $100 / 100$ & $81 / 84$ & $80(16) / 76(18)$ & $31 / 30$ \\
\hline AKDN (ACR)†§ & Canada & $102639(45)$ & $57(14) / 57(16)$ & $56 / 52$ & $48 / 53$ & $78(20) / 76(22)$ & $26 / 24$ \\
\hline CARE & Canada & $4098(14)$ & $58(9) / 61(9)$ & $13 / 20$ & $84 / 91$ & $77(16) / 71(17)$ & $13 / 15$ \\
\hline KEEP & USA & $77902(68)$ & $55(15) / 54(15)$ & $31 / 29$ & $69 / 64$ & $84(22) / 87(24)$ & $13 / 12$ \\
\hline KP Hawaii & USA & $39884(50)$ & $58(15) / 59(15)$ & $50 / 46$ & NA/NA & $79(23) / 80(24)$ & $34 / 33$ \\
\hline MRFIT & USA & $12854(0)$ & $46(6) / \mathrm{NA}$ & 5/NA & $66 /$ NA & $87(13) / \mathrm{NA}$ & 4/NA \\
\hline Pimat & USA & $5066(56)$ & $33(14) / 33(15)$ & $26 / 27$ & $24 / 12$ & $120(18) / 120(20)$ & $18 / 22$ \\
\hline ZODIAC† & Netherlands & $1095(57)$ & $66(12) / 69(11)$ & $100 / 100$ & $83 / 90$ & $76(18) / 66(17)$ & $41 / 38$ \\
\hline High risk total & & $254133(50)$ & $56 / 56$ & $45 / 43$ & $58 / 59$ & $81 / 82$ & $22 / 12$ \\
\hline $\begin{array}{l}\text { General population } \\
\text { and high risk total }\end{array}$ & & $2012546(54)$ & $49 / 49$ & $10 / 8$ & $28 / 27$ & $86 / 88$ & $6 / 5$ \\
\hline \multicolumn{8}{|c|}{ Chronic kidney disease cohorts } \\
\hline AASK $\ddagger$ & USA & $1094(14)$ & $54(11) / 55(11)$ & $0 / 0$ & $100 / 100$ & $46(15) / 44(15)$ & $61 / 63$ \\
\hline
\end{tabular}


Table 1 (continued)

\begin{tabular}{|c|c|c|c|c|c|c|c|}
\hline \multirow[b]{2}{*}{ Study } & \multirow[b]{2}{*}{ Region } & \multirow[b]{2}{*}{$\begin{array}{c}\text { No of participants } \\
\text { (\% women) }\end{array}$} & \multicolumn{5}{|c|}{ Men/women } \\
\hline & & & Mean (SD) age (years) & $\begin{array}{l}\text { \% with } \\
\text { diabetes }\end{array}$ & $\begin{array}{c}\% \text { with } \\
\text { hypertension }\end{array}$ & Mean (SD) eGFR & $\begin{array}{c}\% \text { with } \\
\text { albuminuria* }\end{array}$ \\
\hline $\mathrm{BC} \mathrm{CKD†}$ & Canada & $17426(45)$ & $69(14) / 70(14)$ & $41 / 35$ & $81 / 80$ & $37(19) / 36(19)$ & $79 / 71$ \\
\hline CRIB† & UK & $308(34)$ & $63(13) / 60(16)$ & $16 / 19$ & $95 / 94$ & $24(12) / 19(10)$ & $85 / 89$ \\
\hline Geisinger ACR $\dagger$ & USA & $3361(54)$ & $70(10) / 70(10)$ & $96 / 96$ & $87 / 89$ & $51(9) / 51(8)$ & $49 / 38$ \\
\hline Geisinger dipstick & USA & $4509(61)$ & $72(11) / 72(11)$ & $30 / 25$ & $78 / 75$ & $49(11) / 49(10)$ & $31 / 22$ \\
\hline GLOMMS-1 ACR $\dagger$ & Scotland & $537(51)$ & $72(11) / 74(10)$ & $92 / 93$ & $64 / 64$ & $35(8) / 30(7)$ & $54 / 47$ \\
\hline GLOMMS-1 PCR $\ddagger$ & Scotland & $470(48)$ & $68(15) / 72(15)$ & $22 / 22$ & $63 / 58$ & $30(10) / 28(9)$ & $96 / 95$ \\
\hline KPNW & USA & $1627(56)$ & $71(10) / 72(10)$ & $39 / 38$ & $91 / 93$ & $46(11) / 47(12)$ & $38 / 26$ \\
\hline MASTERPLAN† & Netherlands & $636(31)$ & $62(12) / 58(14)$ & $37 / 30$ & $96 / 94$ & $37(15) / 35(13)$ & $85 / 84$ \\
\hline MDRD & USA & $1730(40)$ & $52(13) / 50(13)$ & $7 / 5$ & NA/NA & $40(20) / 41(22)$ & $82 / 82$ \\
\hline MMKD $\ddagger$ & Multiple ${ }^{\star *}$ & $202(34)$ & $48(12) / 44(13)$ & $0 / 0$ & $89 / 88$ & $49(29) / 44(32)$ & $95 / 94$ \\
\hline NephroTest & France & $928(31)$ & $60(158) / 59(15)$ & $27 / 24$ & $94 / 90$ & $42(20) / 42(22)$ & $65 / 61$ \\
\hline RENAAL $\dagger$ & Multiple†† & $1513(37)$ & $60(8) / 60(7)$ & $100 / 100$ & $96 / 98$ & $44(13) / 36(12)$ & $100 / 100$ \\
\hline STENOT & Denmark & $886(43)$ & $43(11) / 44(11)$ & $100 / 100$ & $65 / 63$ & $89(27) / 80(25)$ & $53 / 45$ \\
\hline Sunnybrook† & Canada & $3385(44)$ & $71(13) / 70(15)$ & $55 / 47$ & $86 / 84$ & $38(15) / 36(17)$ & $85 / 82$ \\
\hline $\begin{array}{l}\text { Chronic kidney } \\
\text { disease total }\end{array}$ & & $38612(47)$ & $67 / 68$ & $46 / 43$ & $84 / 82$ & $42 / 41$ & $72 / 59$ \\
\hline
\end{tabular}

eGFR=estimated glomerular filtration rate. $N A=$ not assessed. Study acronyms and abbreviations listed in appendix 1 on bmj.com.

*Albuminuria defined as urine albumin-creatinine ratio $\geq 30 \mathrm{mg} / \mathrm{g}$ or urine protein-creatinine ratio $\geq 50 \mathrm{mg} / \mathrm{g}$ or urine dipstick protein $\geq 1+$.

†Studies with urine albumin-creatinine ratio.

$\ddagger$ Studies with urine protein-creatinine ratio.

§All participants included in AKDN (Dip), thus not included in the general population and high risk total, and only used for albumin-creatinine ratio analysis

ףCanada, China, Czech Republic, France, Germany, Hungary, Italy, Malaysia, Netherlands, New Zealand, Russia, Slovakia, United Kingdom, Australia, Estonia, India, Ireland, Lithuania, Philippines, Poland

${ }^{* *}$ German speaking Alpine regions.

††Canada, China, Czech Republic, France, Germany, Hungary, Italy, Malaysia, Netherlands, New Zealand, Russia, Slovakia, United Kingdom, Argentina, Austria, Brazil, Chile, Costa Rica, Denmark, Israel, Japan, Mexico, Peru, Portugal, Singapore, Spain, United States of America, Venezuela. 
Table 2| Adjusted hazard ratios of sex-specific categorical analysis of associations of estimated glomerular filtration rate (eGFR) and albuminuria with all-cause mortality and cardiovascular mortality in general population cohorts and high risk cohorts (including the studies with available urine dipstick data). Values are hazard ratios ( $95 \%$ confidence intervals) relative to the reference cell category of eGFR 90-104. The marginal associations of eGFR are in the rightmost column, and those for albuminuria are in the bottom rows for the two sections, each adjusted for each other

\begin{tabular}{|c|c|c|c|c|c|c|c|c|c|c|}
\hline \multirow[b]{3}{*}{ eGFR } & \multicolumn{8}{|c|}{ Albuminuria } & \multirow{2}{*}{\multicolumn{2}{|c|}{$\begin{array}{c}\text { Marginal association } \\
\text { for eGFR }\end{array}$}} \\
\hline & \multicolumn{2}{|c|}{ ACR <10, dipstick - } & \multicolumn{2}{|c|}{ ACR 10-29, dipstick \pm} & \multicolumn{2}{|c|}{ ACR 30-299, dipstick 1+ } & \multicolumn{2}{|c|}{ ACR $\geq 300$, dipstick $\geq 2+$} & & \\
\hline & Men & Women & Men & Women & Men & Women & Men & Women & Men & Women \\
\hline \multicolumn{11}{|c|}{ All-cause mortality } \\
\hline$>105$ & $\begin{array}{l}1.40(1.15 \\
\text { to } 1.71)^{\star}\end{array}$ & $\begin{array}{l}1.24(1.08 \\
\text { to } 1.43)^{*}+\end{array}$ & $\begin{array}{c}1.99(1.41 \text { to } \\
2.82)^{\star}\end{array}$ & $\begin{array}{l}1.72(1.15 \text { to } \\
2.57)^{*}+\end{array}$ & $\begin{array}{c}3.02(2.18 \text { to } \\
4.17)^{*}\end{array}$ & $\begin{array}{c}2.80(1.86 \text { to } \\
4.22)^{\star}\end{array}$ & $\begin{array}{c}5.11(3.41 \text { to } \\
7.67)^{\star}\end{array}$ & $\begin{array}{c}5.56(4.07 \text { to } \\
7.60)^{*}\end{array}$ & $\begin{array}{l}1.34(1.13 \\
\text { to } 1.60)^{*}\end{array}$ & $\begin{array}{l}1.11(0.97 \\
\text { to } 1.28)^{*}+\end{array}$ \\
\hline $90-104$ & \multicolumn{2}{|c|}{ Reference } & $\begin{array}{c}1.52(1.27 \text { to } \\
1.81)^{\star}\end{array}$ & $\begin{array}{c}1.61(1.29 \text { to } \\
2.01)^{*}\end{array}$ & $\begin{array}{c}1.75(1.56 \text { to } \\
1.98)^{\star}\end{array}$ & $\begin{array}{c}2.15(1.73 \text { to } \\
2.67)^{*} \dagger\end{array}$ & $\begin{array}{c}3.13(2.45 \text { to } \\
4.01)^{*}\end{array}$ & $\begin{array}{c}4.05(3.07 \text { to } \\
5.33)^{*} \dagger\end{array}$ & - & - \\
\hline 75-89 & $\begin{array}{l}0.87(0.79 \\
\text { to } 0.96)\end{array}$ & $\begin{array}{l}0.96(0.88 \\
\text { to } 1.05) \dagger\end{array}$ & $\begin{array}{c}1.33(1.22 \text { to } \\
1.46)^{*}\end{array}$ & $\begin{array}{c}1.43(1.26 \text { to } \\
1.63)^{*}\end{array}$ & $\begin{array}{c}1.58(1.40 \text { to } \\
1.79)^{*}\end{array}$ & $\begin{array}{c}1.92(1.68 \text { to } \\
2.20)^{*} \dagger\end{array}$ & $\begin{array}{c}2.39(1.98 \text { to } \\
2.89)^{*}\end{array}$ & $\begin{array}{c}3.04(2.38 \text { to } \\
3.88)^{*} \dagger\end{array}$ & $\begin{array}{l}0.89(0.81 \\
\text { to } 0.98)^{*}\end{array}$ & $\begin{array}{l}0.95(0.88 \\
\text { to } 1.03) \dagger\end{array}$ \\
\hline $60-74$ & $\begin{array}{l}0.98(0.86 \\
\text { to } 1.13)\end{array}$ & $\begin{array}{l}1.02(0.89 \\
\text { to } 1.18) \dagger\end{array}$ & $\begin{array}{c}1.30(1.15 \text { to } \\
1.47)^{\star}\end{array}$ & $\begin{array}{c}1.56(1.41 \text { to } \\
1.72)^{*} \dagger\end{array}$ & $\begin{array}{c}1.77(1.52 \text { to } \\
2.07)^{\star}\end{array}$ & $\begin{array}{c}2.15(1.93 \text { to } \\
2.40)^{*} \dagger\end{array}$ & $\begin{array}{c}2.46(2.02 \text { to } \\
2.99)^{*}\end{array}$ & $\begin{array}{c}3.41(2.74 \text { to } \\
4.23)^{\star} \dagger\end{array}$ & $\begin{array}{c}1.00(0.87 \\
\text { to } 1.14)\end{array}$ & $\begin{array}{l}1.02(0.89 \\
\text { to } 1.17) \dagger\end{array}$ \\
\hline $45-59$ & $\begin{array}{c}1.17(0.97 \\
\text { to } 1.41)\end{array}$ & $\begin{array}{c}1.13(0.94 \\
\text { to } 1.36) \\
\end{array}$ & $\begin{array}{c}1.57(1.32 \text { to } \\
1.87)^{\star}\end{array}$ & $\begin{array}{c}1.83(1.52 \text { to } \\
2.20)^{*}\end{array}$ & $\begin{array}{c}1.93(1.62 \text { to } \\
2.31)^{*}\end{array}$ & $\begin{array}{l}2.33(1.97 \text { to } \\
2.75)^{*} \dagger\end{array}$ & $\begin{array}{c}2.83(2.28 \text { to } \\
3.51)^{\star}\end{array}$ & $\begin{array}{c}3.55(2.80 \text { to } \\
4.51)^{*} \dagger\end{array}$ & $\begin{array}{c}1.16(0.98 \\
\text { to } 1.38) \\
\end{array}$ & $\begin{array}{l}1.12(0.94 \\
\text { to } 1.33)\end{array}$ \\
\hline $30-44$ & $\begin{array}{l}1.51(1.23 \\
\text { to } 1.86)^{\star}\end{array}$ & $\begin{array}{l}1.86(1.42 \\
\text { to } 2.44)^{*} \dagger\end{array}$ & $\begin{array}{c}2.22(1.75 \text { to } \\
2.83)^{\star}\end{array}$ & $\begin{array}{c}2.41(1.90 \text { to } \\
3.05)^{*}\end{array}$ & $\begin{array}{c}2.58(2.14 \text { to } \\
3.12)^{\star}\end{array}$ & $\begin{array}{c}3.25(2.59 \text { to } \\
4.07)^{*} \dagger\end{array}$ & $\begin{array}{c}3.74(2.89 \text { to } \\
4.83)^{*}\end{array}$ & $\begin{array}{c}4.62(3.51 \text { to } \\
6.07)^{*} \dagger\end{array}$ & $\begin{array}{l}1.46(1.21 \\
\text { to } 1.77)^{\star}\end{array}$ & $\begin{array}{l}1.59(1.27 \\
\text { to } 2.00)^{*} \dagger\end{array}$ \\
\hline $15-29$ & $\begin{array}{l}2.84(1.90 \\
\text { to } 4.23)^{\star}\end{array}$ & $\begin{array}{c}3.30(2.29 \\
\text { to } 4.74)^{*}\end{array}$ & $\begin{array}{c}3.52(2.34 \text { to } \\
5.29)^{*}\end{array}$ & $\begin{array}{c}3.85(2.64 \text { to } \\
5.60)^{*}\end{array}$ & $\begin{array}{c}3.98(2.87 \text { to } \\
5.53)^{*}\end{array}$ & $\begin{array}{c}4.60(3.47 \text { to } \\
6.11)^{*}\end{array}$ & $\begin{array}{c}5.35(4.07 \text { to } \\
7.03)^{\star}\end{array}$ & $\begin{array}{c}7.19(5.38 \text { to } \\
9.60)^{*} \dagger\end{array}$ & $\begin{array}{c}2.14(1.70 \\
\text { to } 2.71)^{\star}\end{array}$ & $\begin{array}{l}2.54(1.95 \\
\text { to } 3.31)^{*} \dagger\end{array}$ \\
\hline$<15$ & $\begin{array}{c}4.55(2.38 \\
\text { to } 8.67)^{\star}\end{array}$ & $\begin{array}{l}7.41(3.71 \\
\text { to } 14.80)^{\star}\end{array}$ & $\begin{array}{l}11.54(7.05 \\
\text { to } 18.90)^{*}\end{array}$ & $\begin{array}{c}7.15(4.36 \text { to } \\
11.74)^{\star}\end{array}$ & $\begin{array}{c}7.29(3.52 \text { to } \\
15.08)^{\star}\end{array}$ & $\begin{array}{c}9.75(7.14 \text { to } \\
13.32)^{*} \dagger\end{array}$ & $\begin{array}{c}11.64(8.58 \\
\text { to } 15.79)^{*}\end{array}$ & $\begin{array}{c}16.07(10.44 \\
\text { to } 24.72)^{\star} \dagger\end{array}$ & $\begin{array}{c}3.92(3.09 \\
\text { to } 4.97)^{*}\end{array}$ & $\begin{array}{l}4.93(3.97 \\
\text { to } 6.13)^{*} \dagger\end{array}$ \\
\hline $\begin{array}{l}\text { Marginal } \\
\text { association } \\
\text { for } \\
\text { albuminuria }\end{array}$ & - & - & $\begin{array}{c}1.31(1.21 \text { to } \\
1.46)^{*}\end{array}$ & $\begin{array}{c}1.41(1.27 \text { to } \\
1.57)^{*} \dagger\end{array}$ & $\begin{array}{c}1.66(1.51 \text { to } \\
1.82)^{*}\end{array}$ & $\begin{array}{c}1.85(1.64 \text { to } \\
2.09)^{*} \dagger\end{array}$ & $\begin{array}{c}2.41(2.16 \text { to } \\
2.70)^{*}\end{array}$ & $\begin{array}{c}2.86(2.45 \text { to } \\
3.34)^{*} \dagger\end{array}$ & - & - \\
\hline \multicolumn{11}{|c|}{ Cardiovascular mortality } \\
\hline$>105$ & $\begin{array}{l}1.31(1.02 \\
\text { to } 1.70)^{\star}\end{array}$ & $\begin{array}{c}1.09(0.78 \\
\text { to } 1.53)\end{array}$ & $\begin{array}{c}1.81(1.07 \text { to } \\
3.06)^{\star}\end{array}$ & $\begin{array}{c}2.55(1.25 \text { to } \\
5.17)^{*}\end{array}$ & $\begin{array}{c}4.45(2.70 \text { to } \\
7.33)^{\star}\end{array}$ & $\begin{array}{c}3.00(1.78 \text { to } \\
5.06)^{*}\end{array}$ & $\begin{array}{c}5.73(2.07 \text { to } \\
15.89)^{*}\end{array}$ & $\begin{array}{c}9.76(3.07 \text { to } \\
30.97)^{\star}\end{array}$ & $\begin{array}{l}1.30(1.04 \\
\text { to } 1.63)^{*}\end{array}$ & $\begin{array}{c}1.00(0.77 \\
\text { to } 1.29)\end{array}$ \\
\hline $90-104$ & \multicolumn{2}{|c|}{ Reference } & $\begin{array}{c}1.65(1.29 \text { to } \\
2.12)^{*}\end{array}$ & $\begin{array}{c}1.72(1.34 \text { to } \\
2.21)^{*}\end{array}$ & $\begin{array}{c}1.72(1.37 \text { to } \\
2.17)^{*}\end{array}$ & $\begin{array}{c}2.21(1.65 \text { to } \\
2.94)^{*}\end{array}$ & $\begin{array}{c}3.57(2.36 \text { to } \\
5.38)^{*}\end{array}$ & $\begin{array}{c}4.14(2.67 \text { to } \\
6.43)^{\star}\end{array}$ & - & - \\
\hline 75-89 & $\begin{array}{c}1.01(0.93 \\
\text { to } 1.10)\end{array}$ & $\begin{array}{l}1.13(1.02 \\
\text { to } 1.24)^{*}\end{array}$ & $\begin{array}{c}1.59(1.37 \text { to } \\
1.86)^{\star}\end{array}$ & $\begin{array}{c}1.61(1.31 \text { to } \\
1.97)^{\star}\end{array}$ & $\begin{array}{c}1.83(1.48 \text { to } \\
2.26)^{*}\end{array}$ & $\begin{array}{l}2.12(1.71 \text { to } \\
2.63)^{\star}\end{array}$ & $\begin{array}{c}3.13(2.29 \text { to } \\
4.28)^{\star}\end{array}$ & $\begin{array}{c}3.14(2.31 \text { to } \\
4.26)^{\star}\end{array}$ & $\begin{array}{c}1.02(0.95 \\
\text { to } 1.10)\end{array}$ & $\begin{array}{l}1.11(1.02 \\
\text { to } 1.21)^{\star}\end{array}$ \\
\hline $60-74$ & $\begin{array}{l}1.16(1.06 \\
\text { to } 1.27)^{*}\end{array}$ & $\begin{array}{l}1.27(1.15 \\
\text { to } 1.40)^{*}\end{array}$ & $\begin{array}{c}1.55(1.32 \text { to } \\
1.82)^{\star}\end{array}$ & $\begin{array}{c}1.89(1.55 \text { to } \\
2.30)^{*}\end{array}$ & $\begin{array}{c}2.27(1.92 \text { to } \\
2.68)^{\star}\end{array}$ & $\begin{array}{c}2.53(2.07 \text { to } \\
3.08)^{*}\end{array}$ & $\begin{array}{c}2.85(2.12 \text { to } \\
3.84)^{*}\end{array}$ & $\begin{array}{c}3.67(2.43 \text { to } \\
5.54)^{\star}\end{array}$ & $\begin{array}{l}1.15(1.06 \\
\text { to } 1.24)^{\star}\end{array}$ & $\begin{array}{l}1.27(1.16 \\
\text { to } 1.38)^{*}\end{array}$ \\
\hline $45-59$ & $\begin{array}{c}1.55(1.39 \\
\text { to } 1.73)^{*}\end{array}$ & $\begin{array}{c}1.47(1.18 \\
\text { to } 1.83)^{*}\end{array}$ & $\begin{array}{c}2.05(1.71 \text { to } \\
2.47)^{*}\end{array}$ & $\begin{array}{c}2.32(1.87 \text { to } \\
2.87)^{*}\end{array}$ & $\begin{array}{c}2.41(1.84 \text { to } \\
3.16)^{*}\end{array}$ & $\begin{array}{c}3.20(2.61 \text { to } \\
3.92)^{*} \dagger\end{array}$ & $\begin{array}{c}3.48(2.66 \text { to } \\
4.55)^{*}\end{array}$ & $\begin{array}{c}4.34(3.27 \text { to } \\
5.76)^{*}\end{array}$ & $\begin{array}{l}1.45(1.32 \\
\text { to } 1.59)^{*}\end{array}$ & $\begin{array}{l}1.60(1.36 \\
\text { to } 1.87)^{*} \dagger\end{array}$ \\
\hline $30-44$ & $\begin{array}{c}2.04(1.71 \\
\text { to } 2.45)^{\star}\end{array}$ & $\begin{array}{l}2.92(2.39 \\
\text { to } 3.55)^{*} \dagger\end{array}$ & $\begin{array}{c}3.52(2.54 \text { to } \\
4.88)^{\star}\end{array}$ & $\begin{array}{c}2.77(1.62 \text { to } \\
4.73)^{\star}\end{array}$ & $\begin{array}{c}3.20(2.54 \text { to } \\
4.03)^{\star}\end{array}$ & $\begin{array}{c}4.44(3.25 \text { to } \\
6.05)^{*} \dagger\end{array}$ & $\begin{array}{c}4.74(3.71 \text { to } \\
6.04)^{\star}\end{array}$ & $\begin{array}{c}5.83(4.35 \text { to } \\
7.80)^{*}\end{array}$ & $\begin{array}{l}1.90(1.68 \\
\text { to } 2.16)^{*}\end{array}$ & $\begin{array}{l}2.37(1.94 \\
\text { to } 2.90)^{*} \dagger\end{array}$ \\
\hline $15-29$ & $\begin{array}{l}9.82(4.17 \\
\text { to } 23.13)^{\star}\end{array}$ & $\begin{array}{c}4.81(2.92 \\
\text { to } 7.93)^{*}\end{array}$ & $\begin{array}{c}6.20(2.90 \text { to } \\
13.23)^{\star}\end{array}$ & $\begin{array}{c}5.56(2.58 \text { to } \\
11.99)^{\star}\end{array}$ & $\begin{array}{c}4.43(2.60 \text { to } \\
7.53)^{*}\end{array}$ & $\begin{array}{c}5.57(3.34 \text { to } \\
9.29)^{*}\end{array}$ & $\begin{array}{c}6.66(4.02 \text { to } \\
11.03)^{\star}\end{array}$ & $\begin{array}{c}9.59(6.79 \text { to } \\
13.54)^{*}\end{array}$ & $\begin{array}{c}2.43(1.84 \\
\text { to } 3.22)^{\star}\end{array}$ & $\begin{array}{l}3.58(2.64 \\
\text { to } 4.86)^{*} \dagger\end{array}$ \\
\hline$<15$ & $\begin{array}{l}9.75(2.79 \\
\text { to } 34.07)^{\star}\end{array}$ & $\begin{array}{l}4.55(0.83 \\
\text { to } 24.92)\end{array}$ & $\begin{array}{c}20.90(9.24 \\
\text { to } 47.25)^{*}\end{array}$ & $\begin{array}{c}6.46(1.57 \text { to } \\
26.62)^{\star}\end{array}$ & $\begin{array}{c}5.91(2.94 \text { to } \\
11.86)^{\star}\end{array}$ & $\begin{array}{c}14.23(6.88 \\
\text { to } 29.45)^{*}\end{array}$ & $\begin{array}{c}12.15(6.22 \\
\text { to } 23.73)^{*}\end{array}$ & $\begin{array}{c}8.76(5.13 \text { to } \\
14.99)^{*}\end{array}$ & $\begin{array}{c}4.54(2.42 \\
\text { to } 8.50)^{*}\end{array}$ & $\begin{array}{c}4.09(2.74 \\
\text { to } 6.11)^{\star} \\
\end{array}$ \\
\hline $\begin{array}{l}\text { Marginal } \\
\text { association } \\
\text { for } \\
\text { albuminuria }\end{array}$ & - & - & $\begin{array}{c}1.43(1.33 \text { to } \\
1.53)^{*}\end{array}$ & $\begin{array}{c}1.44(1.33 \text { to } \\
1.57)^{*}\end{array}$ & $\begin{array}{c}1.68(1.46 \text { to } \\
1.93)^{*}\end{array}$ & $\begin{array}{c}2.02(1.73 \text { to } \\
2.36)^{*} \dagger\end{array}$ & $\begin{array}{c}2.21(1.87 \text { to } \\
2.61)^{*}\end{array}$ & $\begin{array}{c}2.94(2.25 \text { to } \\
3.85)^{*} \dagger\end{array}$ & - & - \\
\hline
\end{tabular}

$\mathrm{ACR}=$ urinary albumin-creatinine ratio. Dipstick= dipstick proteinuria.

*Associations that reach $\mathrm{P}<0.05$ compared with the reference category.

†Interactions with sex that reach $\mathrm{P}<0.05$. 


\section{Figures}

Women (with 95\% Cl)

- - Men (with $95 \% \mathrm{Cl}$ )

Reference value (eGFR 95, ACR 5)
- Significant association relative to reference value within each sex

Significant interaction between sex and eGFR or ACR

Mortality by estimated glomerular filtration rate (eGFR)

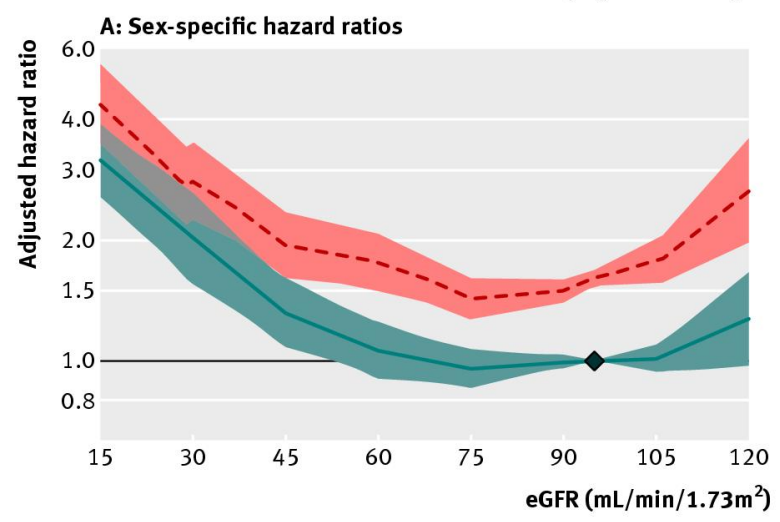

B: Hazard ratios within each sex

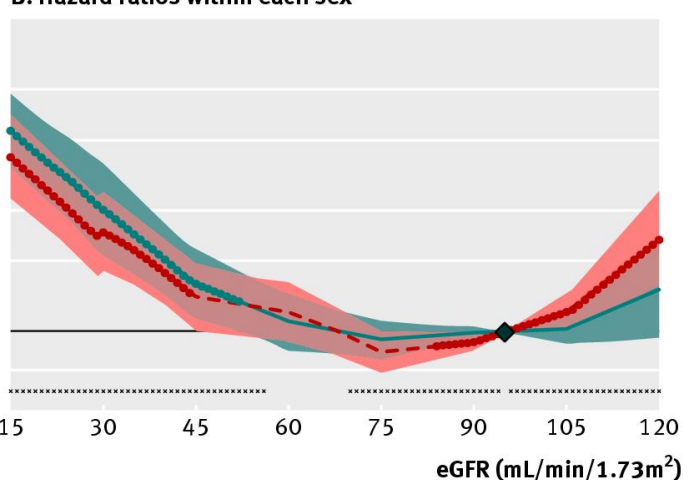

Mortality by urinary albumin-creatinine ratio (ACR)

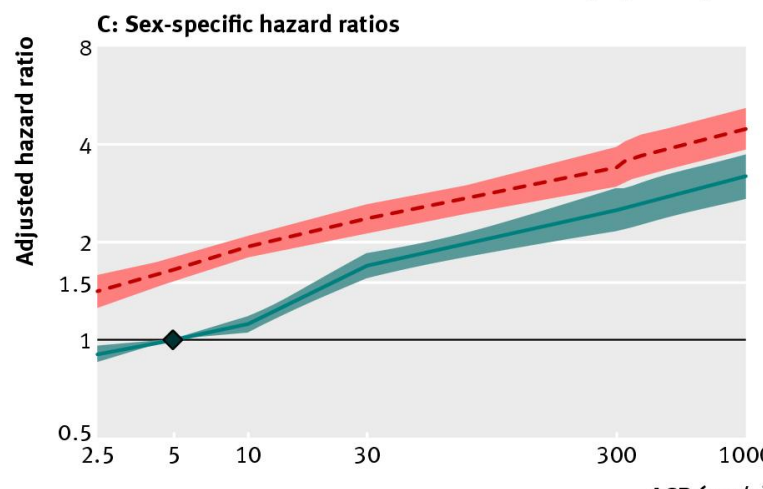

D: Hazard ratios within each sex

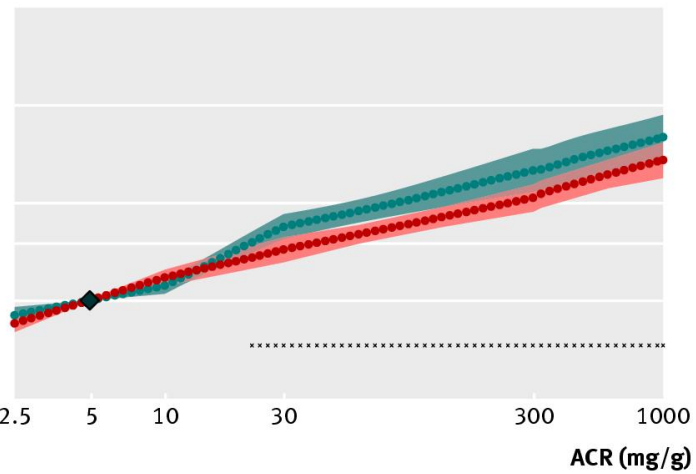

Fig 1 Hazard ratios of all-cause mortality according to estimated glomerular filtration rate (A and $B$ ) and urinary albumin-creatinine ratio $(C$ and $D)$ in men versus women in general population cohorts and high cardiovascular risk cohorts. Panels $A$ and $C$ show sex-specific hazard ratios including a main effect for male sex at the reference point. Panels $B$ and $D$ show hazard ratios within each sex, thus visually removing the baseline difference between men and women. Hazard ratios were adjusted for age, sex, race, smoking status, systolic blood pressure, history of cardiovascular disease, diabetes, serum total cholesterol concentration, body mass index, and estimated glomerular filtration rate splines or albuminuria 


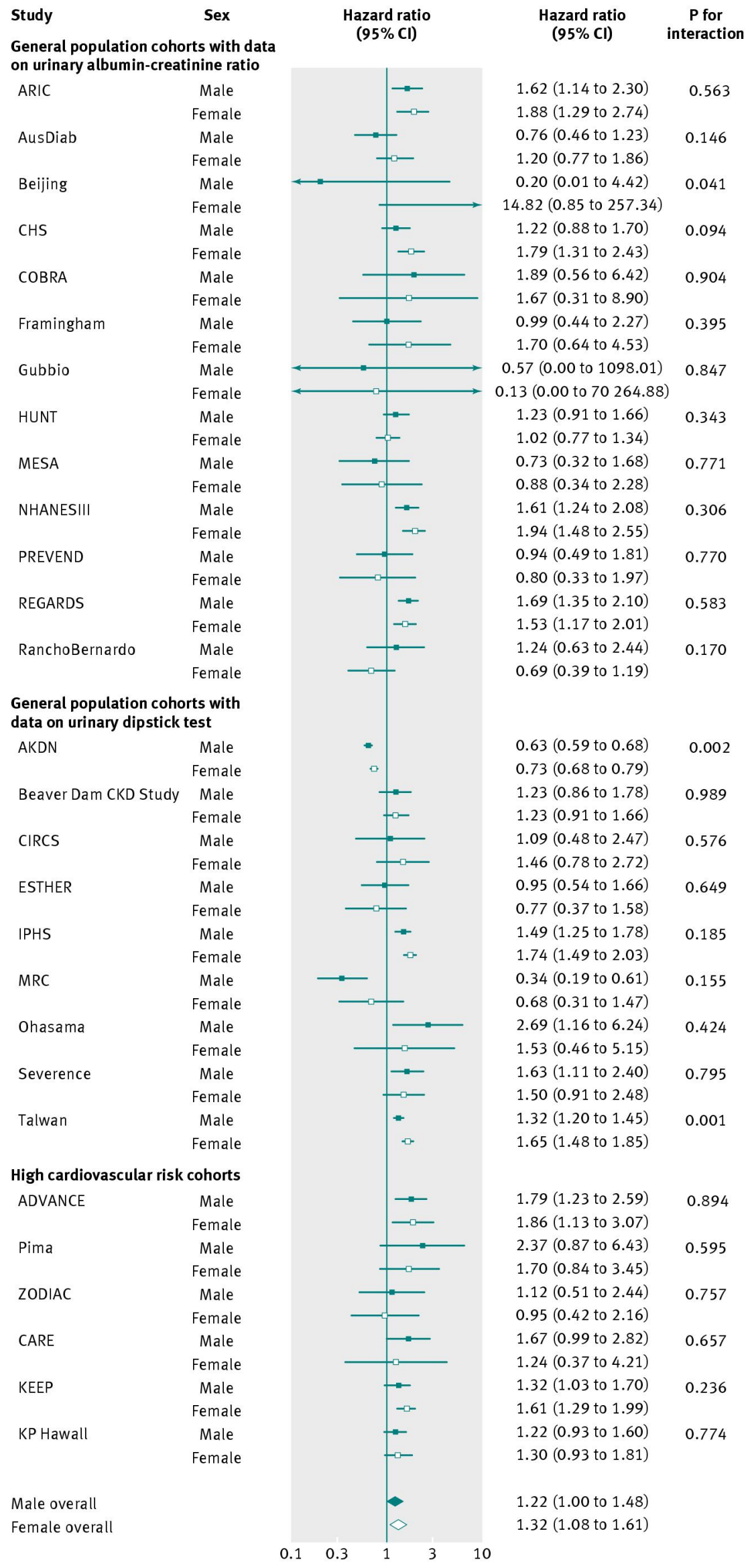

Fig 2 Hazard ratios of all-cause mortality at estimated glomerular filtration rate of 45 ( $v$ rate of 95) in women and men per study. Hazard ratios were adjusted for age, sex, race, smoking status, systolic blood pressure, history of cardiovascular disease, diabetes, serum total cholesterol concentration, body mass index, and albuminuria 


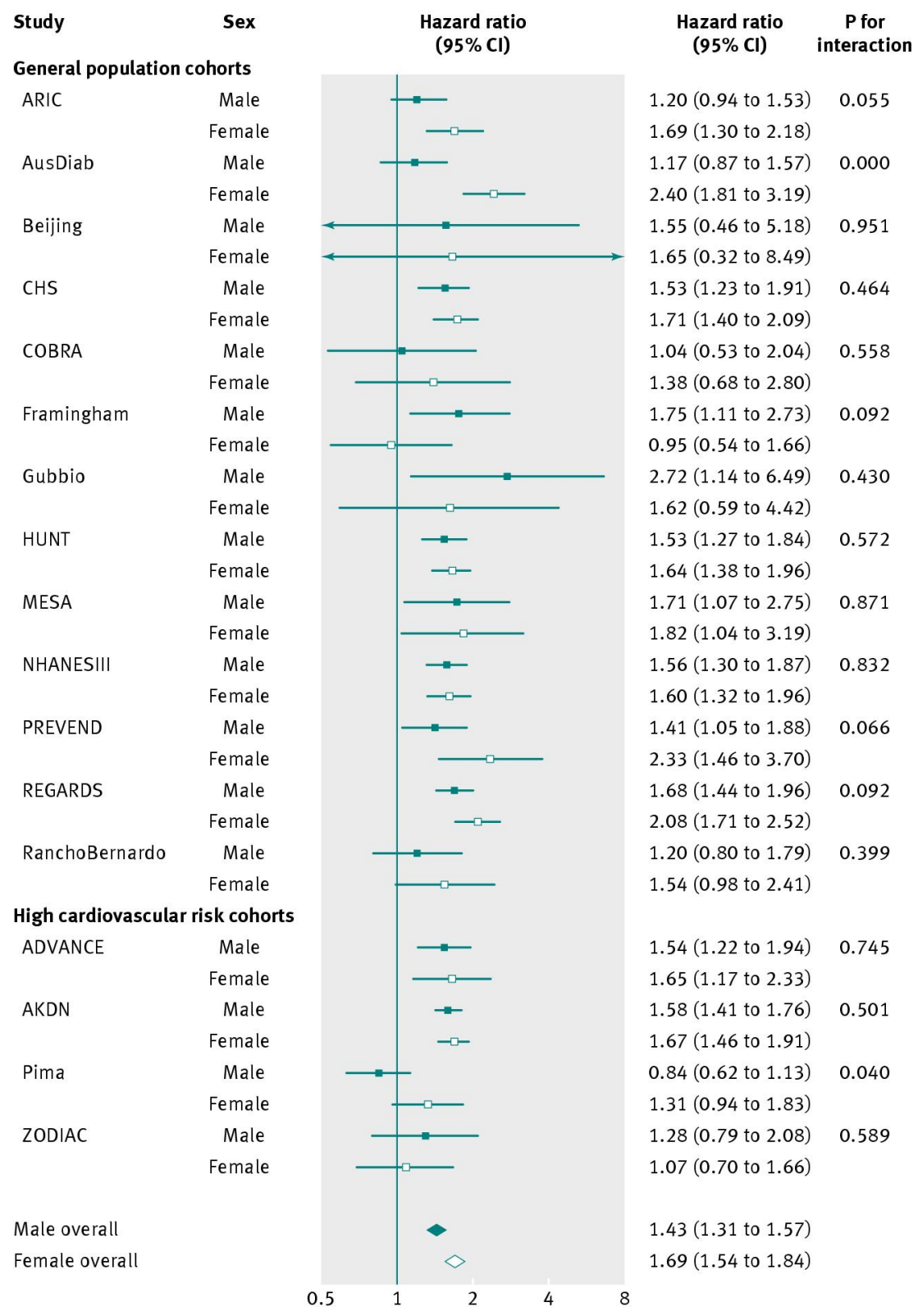

Fig 3 Hazard ratios of all-cause mortality at urinary albumin-creatinine ratio of 30 ( $v$ ratio of 5$)$ in women and men per study. Hazard ratios were adjusted for age, sex, race, smoking status, systolic blood pressure, history of cardiovascular disease, diabetes, serum total cholesterol concentration, body mass index, and estimated glomerular filtration rate splines. 

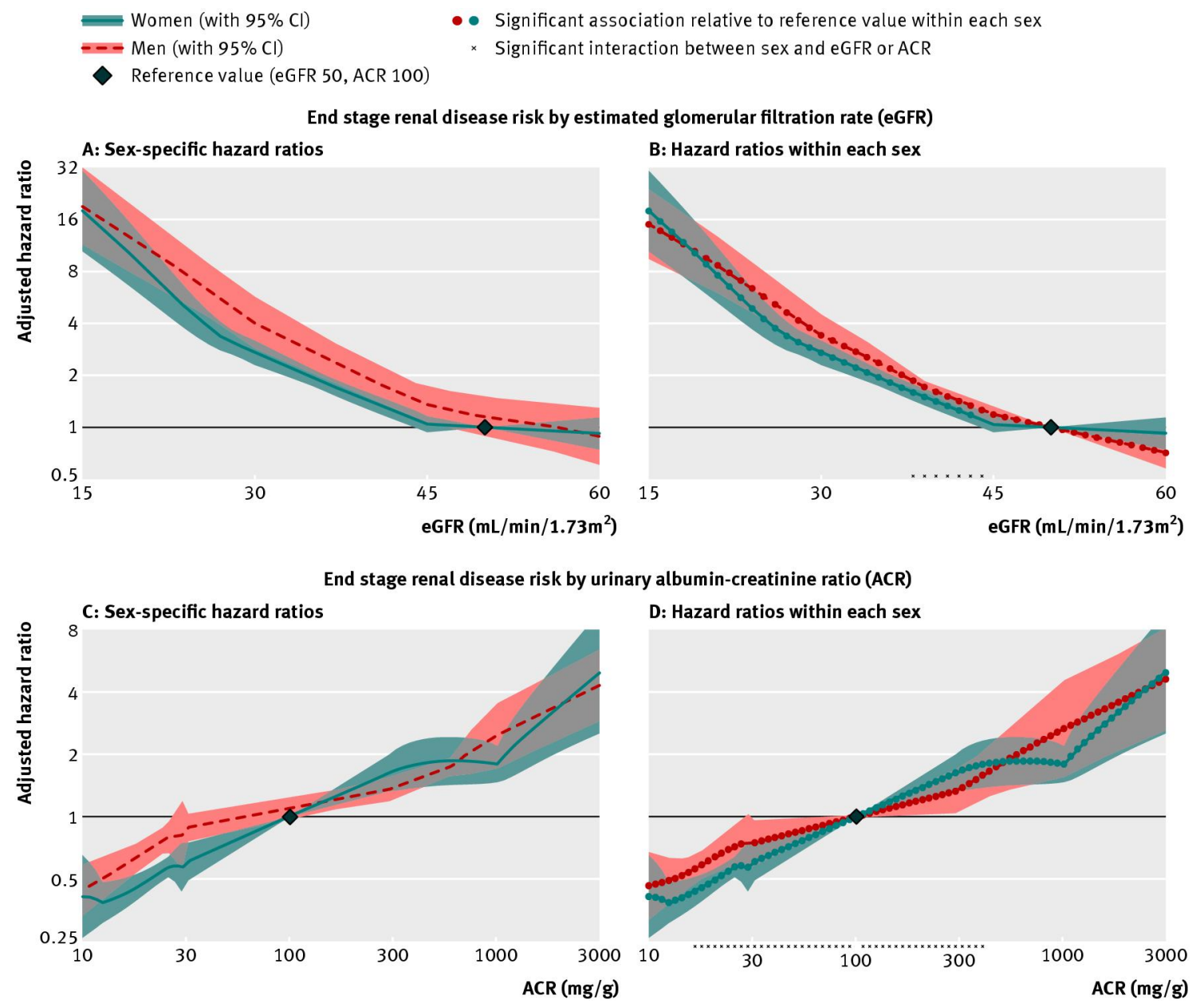

Fig 4 Hazard ratios of end stage renal disease according to estimated glomerular filtration rate (A and B) and urinary albumin-creatinine ratio $(C$ and $D)$ in men versus women in chronic kidney disease cohorts. Panels $A$ and $C$ show sex-specific hazard ratios including a main effect for male sex at the reference point. Panels $B$ and $D$ show hazard ratios within each sex, thus visually removing the baseline difference between men and women. Hazard ratio were adjusted for age, sex, race, smoking status, systolic blood pressure, history of cardiovascular disease, diabetes, serum total cholesterol concentration, body mass index, and estimated glomerular filtration rate splines or albuminuria 